\title{
Ex vivo intestinal studies on calcium and phosphate transport in growing goats fed a reduced nitrogen diet
}

\author{
Alexandra S. Muscher*, Mirja R. Wilkens, Nina Mrochen, Bernd Schröder, Gerhard Breves and \\ Korinna Huber \\ Department of Physiology, University of Veterinary Medicine Hannover, Bischofsholer Damm 15/102, D-30173 Hannover, \\ Germany
}

(Submitted 22 July 2011 - Final revision received 4 October 2011 - Accepted 5 October 2011 - First published online 15 December 2011)

\begin{abstract}
In ruminant feeding, the reduction of dietary protein is an effective approach for decreasing the excretion of N. In non-ruminant species, the intestinal absorption of $\mathrm{Ca}$ was affected when dietary protein was reduced. Therefore, it was the aim of the present study to characterise the intestinal absorption of $\mathrm{Ca}$ and inorganic phosphate $\left(\mathrm{P}_{\mathrm{i}}\right)$ in goats fed different $\mathrm{N}$ and $\mathrm{Ca}$ diets. Intestinal flux rates of Ca and $\mathrm{P}_{\mathrm{i}}$ were determined in goats fed a reduced $\mathrm{N}$ and $\mathrm{Ca}$ diet by Ussing chamber experiments. For a more mechanistic approach, the uptake of Ca and $P_{i}$ in intestinal brush-border membrane vesicles (BBMV), the expression levels of the epithelial Ca channel transient receptor potential vanilloid channel type 6 (TRPV6), the sodium-dependent $\mathrm{P}_{\mathrm{i}}$ transporter (NaPi) IIb and the vitamin D receptor (VDR) were measured. In goats fed a reduced $\mathrm{N}$ and $\mathrm{Ca}$ diet, the intestinal flux rates of $\mathrm{Ca}$ and $\mathrm{P}_{\mathrm{i}}$ were elevated. However, the reduced $\mathrm{N}$ and $\mathrm{Ca}$ diet had no effect on the uptake of $\mathrm{Ca}$ and $\mathrm{P}_{\mathrm{i}}$ in intestinal BBMV, while the expression of TRPV6 and NaPi IIb protein in the corresponding intestinal segments was even decreased. The mRNA expression of NaPi IIb and VDR was not affected. Therefore, a post-transcriptional regulation of TRPV6 and NaPi IIb protein was suggested in goats fed a reduced $\mathrm{N}$ and Ca diet. From these data, it can be concluded that the intestinal absorption of $\mathrm{Ca}$ and $\mathrm{P}_{\mathrm{i}}$ in growing goats was affected by changes in dietary $\mathrm{N}$ and Ca intake like those in single-stomached animals but differently modulated.
\end{abstract}

\section{Key words: Flux rates of calcium and phosphate: Goats: Sodium-dependent phosphate transporter IIb: Transient receptor} potential vanilloid channel type 6: Ussing chambers

In ruminants, feeding low-protein diets is desirable to reduce $\mathrm{N}$ excretion of the animals and thereby decrease the output of $\mathrm{N}$ into the environment. Since excretion of $\mathrm{N}$ is directly correlated with $\mathrm{N}$ intake, a decrease of urinary $\mathrm{N}$ excretion was observed in goats when dietary $\mathrm{N}$ intake was reduced ${ }^{(1,2)}$. Ruminants like goats are able to recycle $\mathrm{N}$ efficiently, in contrast to single-stomached animals, by rumino-hepatic circulation. During dietary N reduction, the renal tubular absorption of urea and the ruminal urea transport capacity were increased $^{(3,4)}$. These adaptive responses ensure an efficient rate of protein synthesis by rumen micro-organisms, whereby microbial protein serves as an amino acid source for the host, especially when dietary $\mathrm{N}$ is deficient. Therefore, ruminants are unique in their capability to cope with reduced $\mathrm{N}$ intake. In contrast, single-stomached animals and humans are not able to utilise endogenous $\mathrm{N}$ sources when consuming a low-protein diet.
In single-stomached animals and humans, metabolic responses to a reduction in dietary protein supply resulted in stunted growth, decreased plasma urea concentrations, diminished urinary excretion of urea and reduced serum insulin-like growth factor-1 (IGF-1) concentrations ${ }^{(5-7)}$. Furthermore, evidence demonstrated that protein metabolism in these species was closely related to other homeostatic systems such as $\mathrm{Ca}$ homeostasis. In rats, a low-protein diet was associated with hypocalciuria, decrease of plasma calcitriol (1,25-dihydroxyvitamin $D_{3}$ ) concentration and reduced intestinal absorption of $\mathrm{Ca}^{(8,9)}$. In humans consuming a low-protein diet, intestinal $\mathrm{Ca}$ absorption rates were reduced and plasma parathyroid hormone concentrations were increased ${ }^{(10)}$.

Concentrations of $11-12 \%$ crude protein (CP) in the diet were suggested to be adequate to meet the requirements for moderate growth performance of young goats ${ }^{(11)}$. Although goats, like all other ruminants, are able to maintain their

Abbreviations: BBMV, brush-border membrane vesicles; BW, body weight; CP, crude protein; FE, fractional excretion; $\mathrm{G}_{\mathrm{T}}$, tissue conductance; IGF-1, insulin-like growth factor-1; $\mathrm{I}_{\mathrm{SC}}$, short-circuit current; $J_{\text {net }}$, net flux rates; $J_{\mathrm{ms}}$, unidirectional flux rates from mucosal to serosal; $J_{\text {sm, }}$ unidirectional flux rates from serosal to mucosal; NaPi IIb, sodium-dependent phosphate transporter; $\mathrm{P}_{\mathrm{i}}$, inorganic phosphate; TRPV6, transient receptor potential vanilloid channel type 6; VDR, vitamin D receptor.

*Corresponding author: Dr A. S. Muscher, fax +49 511856 7687, email alexandra.muscher@tiho-hannover.de 
$\mathrm{N}$ balance of the whole body when fed low-protein diets, the question arises if other processes could be affected like those observed in single-stomached species. This would limit the possibility to reduce $\mathrm{N}$ intake for decreasing environmental pollution due to potential detrimental effects on the metabolic homeostasis and health in ruminants. Interestingly, in two previous studies ${ }^{(12,13)}$, we demonstrated that reducing the dietary $\mathrm{N}$ supply under normocalcaemic and hypocalcaemic conditions had a significant effect on electrolyte metabolism in growing goats, mainly reflected in a decrease of plasma calcitriol concentrations. This reduction of plasma calcitriol is suggested to have an inhibitory effect on the intestinal absorption of $\mathrm{Ca}$ and inorganic phosphate $\left(\mathrm{P}_{\mathrm{i}}\right)$ in ruminants, because it is hypothesised that these processes are calcitriol-dependent like in single-stomached animals ${ }^{(14-16)}$. Consumption of a low-Ca diet, however, led to an increase of plasma calcitriol concentrations which stimulated the intestinal absorption of $\mathrm{Ca}$ in single-stomached animals and humans ${ }^{(17,18)}$. Therefore, the question arises if the reduction in plasma calcitriol concentrations resulting from a reduced $\mathrm{N}$ diet can be counteracted by the stimulation of calcitriol production by a simultaneous decrease in dietary $\mathrm{N}$ and $\mathrm{Ca}$, and if this influences the intestinal electrolyte absorption.

To elucidate this network of $\mathrm{N}$ metabolism and electrolyte homeostasis, growing goats were challenged with two antidromic dietary stimuli, a simultaneous reduction in $\mathrm{N}$ and $\mathrm{Ca}$ intake, to characterise the transport of $\mathrm{Ca}$ and $\mathrm{P}_{\mathrm{i}}$ in the small intestines. For this purpose, unidirectional flux rates of $\mathrm{Ca}$ and $\mathrm{P}_{\mathrm{i}}$ across the intestinal epithelia from goats fed diets with different $\mathrm{N}$ and $\mathrm{Ca}$ content were determined in Ussing chambers. The uptake of $\mathrm{Ca}$ and $\mathrm{P}_{\mathrm{i}}$ into isolated brushborder membrane vesicles (BBMV) and the expression of intestinal transient receptor potential vanilloid channel type 6 (TRPV6), $\mathrm{Na}^{+}$-dependent $\mathrm{P}_{\mathrm{i}}$ transporter (SLC34A2, NaPi IIb) and vitamin $\mathrm{D}$ receptor (VDR) were examined for a more detailed mechanistic approach.

\section{Materials and methods}

The animal feeding and handling regimes were approved by the Animal Welfare Commissioner of the University of Veterinary Medicine Hannover in accordance with the German Animal Welfare Law.

\section{Animals and feeding regimes}

After weaning ( 6 weeks postnatal), twenty male White Saanen goats, purchased from a commercial breeder farm, were separated from their mothers and housed in pens bedded with sawdust. For 2 weeks, all animals were fed a mixture composed of all three concentrate diets and straw in a 4:1 ratio with a CP content of $12 \%$ to allow the goats to acclimatise to pelleted diets. At the age of about 2 months with initial weights of 16.5 (SE 0.5$) \mathrm{kg}$, the goats were allocated to a diet containing either $19 \% \mathrm{CP}$ and $0.7 \% \mathrm{Ca}(19 \% \mathrm{CP} ; n$ 7), $10 \%$ $\mathrm{CP}$ and $0.6 \% \mathrm{Ca}(10 \% \mathrm{CP} ; n 7)$ or $7 \% \mathrm{CP}$ and $0.5 \% \mathrm{Ca}(7 \%$ $\mathrm{CP} ; n$ 6), for 7-9 weeks. To maintain the $\mathrm{Ca}: \mathrm{P}_{\mathrm{i}}$ ratio in the diets, $\mathrm{P}_{\mathrm{i}}$ was adjusted. The contents of each diet were assessed on an as-fed basis. The animals were housed in groups of six to seven on wooden shavings with water available ad libitum. The fed amount of concentrate per animal and day was $70 \mathrm{~g} / \mathrm{kg}$ metabolic body weight $\left(\mathrm{BW}^{0.75}\right)$. Additionally, $33 \%$ of the concentrate weight was given as chopped wheat straw and feeding was performed three times daily. Food was placed in broad feeding troughs to allow undisturbed food intake for each animal in the group. The total amounts of all feeds offered and refused were monitored daily to estimate the mean daily intake of nutrients and minerals over the entire experimental period (Table 2).

\section{Diets}

Dietary ingredients have been described in detail elsewhere ${ }^{(3,12)}$. The feed contents of DM, crude ash, crude fibre, crude fat and CP were determined by standard procedure in accordance with the methods of the Association of German Agricultural Investigation and Research Centre ${ }^{(19)}$. The components and composition of wheat straw and concentrates are presented in Table 1. Sipernat 22S, a fine particle silica, which cannot be metabolised, was used to adjust the weight of reduced $\mathrm{N}$ diets.

\section{Blood and urine samples}

Plasma samples were taken $24 \mathrm{~h}$ before slaughter. Blood samples $(9 \mathrm{ml}$ each) were taken by venepuncture from the vena jugularis with EDTA or lithium heparinate covered syringes (Sarstedt, Nümbrecht, Germany). Blood plasma was separated by centrifugation ( $2000 \boldsymbol{g}$ at room temperature for $15 \mathrm{~min}$ ) and stored at $-20^{\circ} \mathrm{C}$. Urine samples were collected during slaughter by aspiration from the bladder. For one goat in the $19 \% \mathrm{CP}$ group, no urine was present in the bladder.

\section{Intestinal tissue samples}

At the end of the study, the animals (3-4 months of age) were slaughtered by exsanguination after captive bolt stunning. Within 3-5 min after slaughter, segments of about $60 \mathrm{~cm}$ in length from the proximal and mid-jejunum were removed from the abdominal cavity beginning $1 \mathrm{~m}$ distal from the pylorus. Intestinal segments were rinsed with ice-cold saline $(0.9 \% \mathrm{w} / \mathrm{v})$ and kept in a glucose-containing Krebs-Henseleit buffer solution, continuously aerated with carbogen (95\% $\mathrm{O}_{2}-5 \% \mathrm{CO}_{2}$ ) until the tissue preparations were mounted in Ussing chambers ${ }^{(20,21)}$. For RNA isolation, nuclear extracts and preparation of plasma membrane-enriched fractions, samples were rinsed with ice-cold saline $(0.9 \% \mathrm{w} / \mathrm{v})$. The mucosa of the proximal and mid-jejunum was stripped off, frozen in liquid $\mathrm{N}_{2}$ and stored at $-80^{\circ} \mathrm{C}$ immediately.

\section{Intestinal flux rate measurements of calcium and inorganic phosphate}

Determination of $\mathrm{Ca}, \mathrm{P}_{\mathrm{i}}$ and mannitol flux rates across the intestinal epithelia was performed in Ussing chambers with an exposed surface of $1.13 \mathrm{~cm}^{2}$ under short-circuit current 
Table 1. Components and composition of wheat straw and pelleted concentrate diets*

\begin{tabular}{|c|c|c|c|c|}
\hline & Wheat straw & $19 \% \mathrm{CP}$ & $10 \% \mathrm{CP}$ & $7 \% \mathrm{CP}$ \\
\hline \multicolumn{5}{|c|}{ Components, g/kg (as-fed basis) } \\
\hline Beet pulp & _- & 425 & 425 & 455 \\
\hline Tapioca & - & 407 & 407 & 452 \\
\hline Soyabean meal & - & 108 & 108 & 33 \\
\hline Soyabean oil & - & 10 & 10 & 10 \\
\hline Mineral-vitamin mix† & - & 10 & 10 & 10 \\
\hline $\mathrm{MgHPO}_{4} \cdot 3 \mathrm{H}_{2} \mathrm{O}$ & - & 4 & 4 & 6 \\
\hline Urea & - & 30 & - & - \\
\hline Sipernat 22S $\ddagger$ & - & 6 & 36 & 34 \\
\hline \multicolumn{5}{|l|}{ Composition } \\
\hline DM $(\mathrm{g} / \mathrm{kg})$ & 907 & 966 & 962 & 961 \\
\hline \multicolumn{5}{|l|}{ Nutrient (g/kg DM) } \\
\hline Crude ash & $56 \cdot 2$ & $58 \cdot 0$ & $87 \cdot 3$ & 89.5 \\
\hline $\mathrm{CP}$ & 37.5 & 200 & 101 & 69.7 \\
\hline Crude fat & $6 \cdot 6$ & $22 \cdot 8$ & $19 \cdot 8$ & $17 \cdot 7$ \\
\hline Urea & BDL & $32 \cdot 1$ & BDL & $\mathrm{BDL}$ \\
\hline $\mathrm{Ca}$ & 2.8 & $7 \cdot 1$ & 6.1 & 4.6 \\
\hline $\mathrm{P}$ & 0.8 & $2 \cdot 8$ & 2.5 & $2 \cdot 1$ \\
\hline Vitamin $D_{3}$ & BDL & $\mathrm{BDL}$ & $\mathrm{BDL}$ & $\mathrm{BDL}$ \\
\hline DCAD (mEg/kg DM) & - & 210 & 210 & 200 \\
\hline ME (MJ/kg DM) & $6 \cdot 4$ & $13 \cdot 0$ & $12 \cdot 2$ & $12 \cdot 1$ \\
\hline
\end{tabular}

$\mathrm{CP}$, crude protein; $\mathrm{BDL}$, below detection level; DCAD, dietary cation anion difference; ME, metabolisable energy.

${ }^{*}$ Composition expressed as fed.

† Mineral-vitamin mix per kg: $180 \mathrm{~g} \mathrm{Ca} ; 60 \mathrm{~g} \mathrm{P} ; 100 \mathrm{~g} \mathrm{Na}^{+} ; 30 \mathrm{~g} \mathrm{Mg} ; 500000 \mathrm{IU}(525 \mu \mathrm{mol} / \mathrm{l})$ vitamin A; $80000 \mathrm{IU}$ (4992 nmol/l) vitamin $D_{3} ; 300 \mathrm{mg}(697 \mu \mathrm{mol} / \mathrm{l})$ vitamin E; $4200 \mathrm{mg} \mathrm{Zn;} 900 \mathrm{mg} \mathrm{Mn;} 16 \mathrm{mg} \mathrm{Co} ; 20 \mathrm{mg}$ iodine; $44 \mathrm{mg}$ Se.

‡ Sipernat type 22S (Evonik Industries AG, Essen, Germany) is a fine particle silica with high oil absorption capacity. It is widely used as flow regulator, anti-caking and dusting agent especially in the food and feed industry.

conditions as described by Schröder et al. ${ }^{(20,21)}$. The tissue conductance and the short-circuit current were determined by a computer-controlled voltage clamp device (Mussler Scientific Instruments, Aachen, Germany). Tissues were incubated on both sides with a $10 \mathrm{ml}$ buffer solution (adjusted under carbogen saturation to $\mathrm{pH} 7 \cdot 4$ at $38^{\circ} \mathrm{C}$ with $\mathrm{HCl}$ ) containing (mM): $113.6 \mathrm{NaCl}, 5 \cdot 4 \mathrm{KCl}, 1 \cdot 2 \mathrm{MgCl}_{2} \cdot 6 \mathrm{H}_{2} \mathrm{O}, 21 \cdot 0$ $\mathrm{NaHCO}_{3}, \quad 1 \cdot 2 \mathrm{CaCl}_{2} \cdot 2 \mathrm{H}_{2} \mathrm{O}, \quad 1 \cdot 2 \quad \mathrm{Na}_{2} \mathrm{HPO}_{4} .2 \mathrm{H}_{2} \mathrm{O}$ and 1.2 mannitol, respectively. The serosal buffer additionally contained $10.0 \mathrm{~mm}$-glucose and $0.01 \mathrm{~mm}$-indomethacin. During the experiments, the buffers were continuously aerated with carbogen at $38^{\circ} \mathrm{C}$. After the tissue had been equilibrated for $30 \mathrm{~min},{ }^{45} \mathrm{Ca},{ }^{32} \mathrm{P}$ and $\left({ }^{3} \mathrm{H}\right)$-mannitol (each about $185 \mathrm{kBq} /$ chamber) were used as radioisotopic tracers (Hartmann, Brunswick, Germany). Samples were taken at intervals of $10 \mathrm{~min}$ and replaced with equal volumes of the buffer solution. Radioactivity of the samples was measured by a liquid scintillation counter (Tri-Carb 2500 TR Packard Instruments Company, Downers Grove, IL, USA). The $\left({ }^{3} \mathrm{H}\right)$-mannitol was used as a paracellular marker ${ }^{(22)}$. Unidirectional flux rates from mucosal to serosal $\left(J_{\mathrm{ms}}\right)$ and serosal to mucosal $\left(J_{\mathrm{sm}}\right)$ of $\mathrm{Ca}, \mathrm{P}_{\mathrm{i}}$ and mannitol were calculated from the rate of tracer appearance on the unlabelled side using standard equations $^{(23)}$. Net flux rates $\left(J_{\text {net }}\right)$ were determined as differences between $J_{\mathrm{ms}}$ and $J_{\mathrm{sm}}$ of paired tissues.

\section{Biochemical determinations}

Haematocrit was determined in whole blood samples. An aliquot of each blood sample was placed in a microhaematocrit tube and spun to constant packed cell volume at $14926 \mathrm{~g}$ for $5 \mathrm{~min}$ at room temperature. Plasma and urine urea concentrations were measured using a commercial kit (R-Biopharm, Darmstadt, Germany). The inter- and intraassay CV for urea were 2.7 and $1 \%$, respectively. Plasma and urine creatinine were analysed by a standard diagnostic method in the Clinic for Diseases of Cattle at the University of Veterinary Medicine in Hannover. Total plasma protein concentration was measured with a commercial Coomassie blue protein assay (Bio-Rad, Munich, Germany) using bovine plasma gamma globulin as standard protein. Inter- and intraassay CV of protein were 1.2 and $1.0 \%$, respectively. Plasma albumin concentrations were detected by a standard dye binding technique using bromocresol green (Hengler Analytik, Steinbach, Germany). Inter- and intra-assay CV of albumin were 7.7 and $2.3 \%$, respectively. Ionised $\mathrm{Ca}$ was measured in whole blood samples using an ion-sensitive electrode (Chiron Diagnostics $\mathrm{GmbH}$, Wiesentheid, Germany). Interand intra-assay $\mathrm{CV}$ of ionised Ca were 2 and $1 \%$, respectively. Concentrations of total $\mathrm{Ca}$ and inorganic $\mathrm{P}_{\mathrm{i}}$ were measured colorimetrically in plasma and urine by standard spectrometric techniques ${ }^{(24,25)}$. Inter- and intra-assay $\mathrm{CV}$ of total Ca were $4 \cdot 4$ and $2.4 \%$ and for $\mathrm{P}_{\mathrm{i}}$ they were 3.7 and $1.9 \%$, respectively. $\mathrm{Na}^{+}$ concentrations in plasma and urine were detected using a $\mathrm{Na}^{+}$-selective electrode (ABX Pentra 400; Horiba ABX, Montpellier, France). Inter- and intra-assay $\mathrm{CV}$ of $\mathrm{Na}^{+}$were 0.4 and $0.2 \%$, respectively. The concentration of calcidiol was determined by a competitive EIA (Immundiagnostik AG, Bensheim, Germany). The declared inter- and intra-assay CV of the kit were $<13.2$ and $<10 \cdot 7 \%$, respectively. Calcitriol concentrations were measured by a commercial radioreceptor assay (Immundiagnostik AG). The intra-assay CV were $<15$ and $<10 \%$ for samples with calcitriol concentrations of 10 and $60 \mathrm{pg} / \mathrm{ml}$, respectively. The inter-assay CV were $<20$ 
and $<15 \%$ for these two concentrations. The detection limit of this assay was $2 \mathrm{pg} / \mathrm{ml}$. The calcitriol assay systems had already been used in other studies to determine the concentration of this hormone in goat plasma ${ }^{(26-28)}$. For total plasma IGF-1 determination, an ACTIVE IGF-1 coated tube IRMA Kit (DSL-5600; Diagnostic Systems Laboratories, Inc., Webster, TX, USA) was used. The IGF-1 was separated from its binding proteins by an acid-ethanol extraction procedure, and IGF-1 concentrations were determined with a two-site immunoradiometric assay. The intra-assay CV was $1.5-3.5 \%$ and the inter-assay $\mathrm{CV}$ was $1.5-8.5 \%$. The amount of growth hormone was measured by an ELISA as previously described $^{(13,29,30)}$. Intra- and inter-assay CV were $9 \cdot 8$ and $12.6 \%$, respectively. The lowest detection limit was $1.0 \mathrm{ng} / \mathrm{ml}$ and the $\mathrm{ED}_{50}$ in this assay system was $7.6 \mathrm{ng} / \mathrm{ml}$.

\section{Calculation of fractional excretion}

The fractional excretion (FE) of urea was determined at the end of the experimental period using the following formula:

$$
\text { FE urea }=\frac{\text { Creatinine }_{\text {plasma }}(\mathrm{mm}) \times \text { Urea }_{\text {urine }}(\mathrm{mm})}{\text { Creatinine }_{\text {urine }}(\mathrm{mm}) \times \text { Urea }_{\text {plasma }}(\mathrm{mm})} \times 100 \% \text {. }
$$

The FE of total $\mathrm{Ca}, \mathrm{P}_{\mathrm{i}}$ and $\mathrm{Na}^{+}$was calculated by applying the same equation, but with the respective values for total $\mathrm{Ca}, \mathrm{P}_{\mathrm{i}}$ and $\mathrm{Na}^{+}$. The reliability of creatinine for measuring the renal function during protein reduction was suitably shown by Valtonen et al. ${ }^{(31)}$.

\section{Isolation of intestinal brush-border membrane vesicles, calcium and inorganic phosphate uptake studies}

The preparation of small-intestinal BBMV, $\mathrm{Ca}$ and $\mathrm{P}_{\mathrm{i}}$ uptake studies have already been described by Schröder et al. ${ }^{(27)}$ and Muscher et $a l^{(26)}$. Briefly, BBMV from proximal and mid-jejunum were prepared according to a $\mathrm{Mg}^{2+}$ precipitation method, with two precipitation steps.

The uptake of $\mathrm{Ca}$ in BBMV of proximal jejunum was performed using a method described by Kaune et al. ${ }^{(32)}$ with slight modifications. For the uptake of ${ }^{45} \mathrm{Ca} / \mathrm{Ca}, \mathrm{BBMV}$ of proximal jejunum were incubated at $21^{\circ} \mathrm{C}$, with the uptake medium containing $75 \mathrm{~mm}$-mannitol, $75 \mathrm{~mm}-\mathrm{KCl}, 7.5 \mathrm{~mm}$-HEPES-Tris, 0.5 mm-ethylene glycol tetraacetic acid, non-labelled $\mathrm{Ca}$ and $37 \mathrm{kBq} /$ incubation vessel ${ }^{45} \mathrm{Ca}$ (Hartmann). The desired free $\mathrm{Ca}$ concentrations were obtained by adding appropriate amounts of $\mathrm{Ca}$ to $0.5 \mathrm{~mm}$-ethylene glycol tetraacetic acid. The amounts of Ca were calculated by Winmax32 version 2.50 (Chris Patton, Stanford University, USA; http://www.stanford. edu/ $\sim$ cpatton/maxc.html). The concentration-dependent $\mathrm{Ca}$ uptakes were performed over a range of 0.045-4.0 mM-Ca.

For the uptake of ${ }^{32} \mathrm{P} / \mathrm{P}_{\mathrm{i}}$, BBMV of mid-jejunum were incubated at $21^{\circ} \mathrm{C}$ with the uptake medium containing nonlabelled $\mathrm{P}_{\mathrm{i}}$ and $\alpha{ }^{32} \mathrm{P}$ (Hartmann; $37 \mathrm{kBq} /$ incubation vessel). Concentration-dependent $\mathrm{P}_{\mathrm{i}}$ uptakes were performed over a range of $0.01-1.0 \mathrm{~mm}-\mathrm{P}_{\mathrm{i}}$. Extravesicular incubation buffer

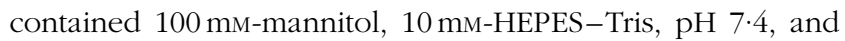

$100 \mathrm{~mm}-\mathrm{NaCl}$. The $\mathrm{Na}^{+}$dependency of $\mathrm{P}_{\mathrm{i}}$ transport was established by incubating BBMV of mid-jejunum in solutions in which $\mathrm{KCl}$ replaced $\mathrm{NaCl}$ equimolarly. The proximal BBMV were washed with a stop solution containing $150 \mathrm{~mm}-$ $\mathrm{KCl}$, $50 \mathrm{~mm}$-mannitol, $10 \mathrm{~mm}$-HEPES-Tris and $1 \mathrm{~mm}$-ethylene glycol tetraacetic acid, $\mathrm{pH} 7 \cdot 4$, while the BBMV from midjejunum were washed with $150 \mathrm{~mm}-\mathrm{KCl}, 1 \mathrm{~mm}-\mathrm{KH}_{2} \mathrm{PO}_{4}$ and $10 \mathrm{~mm}$-HEPES-Tris, $\mathrm{pH} 7.4$, both on $0.65 \mu \mathrm{m}$ cellulose nitrate filters. The activity of each filter was counted using a Packard Tri-Carb 2500TR scintillation counter. Kinetic parameters $V_{\max }$ $\left(\mathrm{nmol} \mathrm{Ca} /(\mathrm{mg}\right.$ protein $\times 30 \mathrm{~s})$ or $\mathrm{nmol} \mathrm{P}_{\mathrm{i}} /(\mathrm{mg}$ protein $\left.\times 10 \mathrm{~s})\right)$ and $K_{\mathrm{m}}(\mathrm{mm})$ were calculated from the Michaelis-Menten kinetic of $\mathrm{Ca}$ or $\mathrm{P}_{\mathrm{i}}$ uptake into the intestinal BBMV.

\section{Intestinal expression of sodium-dependent phosphate} transporter $I / b$ and vitamin D receptor $m R N A$ in goats fed a $19 \%$ crude protein v. $7 \%$ crude protein diet

Semi-quantitative detection of specific amounts of $\mathrm{NaPi} \mathrm{IIb}$ and VDR mRNA in caprine proximal and mid-jejunum was performed via Northern blot analysis as described in detail elsewhere ${ }^{(26,33)}$. Briefly, isolated $6 \mu \mathrm{g}$ poly $(\mathrm{A})^{+} \mathrm{RNA} / \mathrm{lane}$ from proximal or mid-jejunum was fractionated in $1.0 \%$ formamide/agarose gels and transferred by capillary blotting onto nitrocellulose membranes. Radioactive ${ }^{32} \mathrm{P}$-labelled NaPi IIb, VDR- and ß-actin-specific probes were hybridised to fixed mRNA. Hybridisation took place for $16 \mathrm{~h}$ at $42^{\circ} \mathrm{C}$ (40\% formamide). The membranes were analysed with a phosphorous imager system (Bio-Rad) after exposure to a phosphorous imager screen for $2-6 \mathrm{~h}$. The relative amounts of specific mRNA were quantified by reference to $\beta$-actin as an internal standard using the quantification software Quantity One (Bio-Rad).

Intestinal expression of transient receptor potential vanilloid channel type 6, sodium-dependent phosphate transporter $I / b, \mathrm{Na}^{+} \mathrm{K}^{+}$ATPase and vitamin $\mathrm{D}$ receptor protein in goats fed a $19 \%$ crude protein v. $7 \%$ crude protein diet

Mucosa samples from proximal and mid-jejunum were homogenised and crude membranes prepared by performing differential centrifugation ${ }^{(34)}$. From mid-jejunum, BBM were isolated using the $\mathrm{Mg}^{2+}$ precipitation method previously described. The isolation of nuclear extracts from caprine proximal and mid-jejunum was carried out by a method described by Schröder et $a l .^{(35)}$ and Muscher et $a l .{ }^{(26)}$. The protein concentrations of all preparations were determined by the Bradford method (Bio-Rad). Immunoblot assays detecting TRPV6, NaPi IIb and VDR proteins in caprine intestinal tissues were performed as previously described ${ }^{(26,34)}$. For the abundance of TRPV6, NaPi IIb and $\mathrm{Na}^{+} \mathrm{K}^{+}$ATPase, $15-50 \mu \mathrm{g}$ of enriched plasma membranes or $\mathrm{BBM}$ were separated by 8.5\% SDS-PAGE and transferred to nitrocellulose membranes (GE Healthcare, Freiburg, Germany) using a tank blotting system (Bio-Rad). For the detection of VDR, $15 \mu \mathrm{g}$ of nuclear extracts were separated in 10\% SDS-polyacrylamide gels in the same manner. Nitrocellulose membranes were blocked 
Table 2. Effects of a reduced nitrogen and calcium diet on the performance of growing goats as estimated from pooled group mean values over the entire experimental period

(Mean values)

\begin{tabular}{lccc}
\hline Item & $19 \% \mathrm{CP}$ & $10 \% \mathrm{CP}$ & $7 \% \mathrm{CP}$ \\
\hline$n$ & 7 & 7 & 6 \\
DM intake $(\mathrm{g} / \mathrm{d})^{\star}$ & 701 & 751 & 558 \\
Concentrate intake $(\mathrm{g} / \mathrm{d}) \dagger$ & 598 & 599 & 431 \\
$\mathrm{~N}$ intake $(\mathrm{g} / \mathrm{d})^{\star} \dagger$ & $18.7 \dagger$ & 10.2 & 5.5 \\
$\mathrm{Ca}$ intake $(\mathrm{g} / \mathrm{d}) \dagger$ & 4.5 & 4.0 & 2.3 \\
$\mathrm{P}$ intake $(\mathrm{g} / \mathrm{d})$ & 1.7 & 1.6 & 1.0 \\
Initial body weight $(\mathrm{kg})$ & 16.5 & 16.7 & 16.2 \\
Final body weight $(\mathrm{kg})$ & 21.8 & 23.4 & 19.8 \\
Body weight gain $(\mathrm{kg} / \mathrm{d})^{*}$ & 0.101 & 0.137 & 0.059
\end{tabular}

$\mathrm{CP}$, crude protein.

${ }^{*}$ Results have previously been published in Muscher et al. ${ }^{(3)}$.

† Results in the $19 \% \mathrm{CP}$ and $7 \% \mathrm{CP}$ columns were previously published in Muscher et al. ${ }^{(12)}$.

overnight at $4^{\circ} \mathrm{C}$ in PBS containing fat-free milk powder. Immunodetection of electrotransferred proteins was performed according to standard procedures. The following primary antibodies were used: anti-TRPV6 (H-90; Santa Cruz Biotechnology, Heidelberg, Germany), anti-NaPi IIb (gift from Professor Dr J. Biber), anti-VDR (Enzo Life Sciences GmbH, Lörrach, Germany), anti-villin (Biotrend Chemikalien $\mathrm{GmbH}$, Cologne, Germany) and anti-Na ${ }^{+} \mathrm{K}^{+}$ATPase (Enzo Life Sciences $\mathrm{GmbH}$ ). Immunoreactive proteins were visualised using the enhanced chemiluminescence system (Perbio Science GmbH, Bonn, Germany) according to the manufacturer's protocol. Villin was used as an internal standard to semiquantify relative protein expression amounts. Bands were analysed semiquantitatively using the Quantity One software (Bio-Rad).

\section{Statistical analysis}

All data are expressed as means with their pooled standard errors, with number of animals. Data were analysed by one-way ANOVA with Tukey's post test except Northern and Western Blot analyses which were analysed by unpaired Student's $t$ test. Kinetic parameters of $\mathrm{Ca}$ or $\mathrm{P}_{\mathrm{i}}$ uptake into isolated BBMV were calculated using non-linear regression analysis. Potential relationships between the measured parameters were calculated by linear regression analysis. All statistical analyses were performed using GraphPad Prism version 4.0 for Windows (GraphPad Software, San Diego, CA, USA, www.graphpad.com). In all cases, $P<0.05$ was set to be significantly different and $P<0 \cdot 1$ was used to define trends.

\section{Results}

Intake, body weight and daily weight gain

Daily DM, concentrate, N, Ca and P intake on a per-animal basis were estimated from group mean values. Mean daily DM, concentrate, N, Ca and P intake, BW gain, and BW over the entire experimental period are summarised in Table 2. Some of these results have already been published by Muscher et al. ${ }^{(3,12)}$.

\section{Blood parameters as affected by the reduction of dietary nitrogen and calcium in growing goats}

The haematocrit, total plasma protein and albumin content in the growing goats fed a reduced $\mathrm{N}$ and $\mathrm{Ca}$ diet remained unchanged throughout the complete experimental period,

Table 3. Effects of a reduced nitrogen and calcium diet on blood parameters of growing goats*

(Mean values and pooled standard errors)

\begin{tabular}{|c|c|c|c|c|c|}
\hline Item & $19 \% \mathrm{CP} \dagger$ & $10 \% \mathrm{CP}$ & $7 \% \mathrm{CP} \dagger$ & SEM & $P$ \\
\hline$n$ & 7 & 7 & 6 & & \\
\hline \multicolumn{6}{|l|}{ Total blood } \\
\hline Haematocrit (\%) & $26 \cdot 6$ & $27 \cdot 3$ & $27 \cdot 6$ & 2.09 & 0.86 \\
\hline lonised $\mathrm{Ca}(\mathrm{mM})$ & $1.40^{\mathrm{a}}$ & $1 \cdot 29^{b}$ & $1 \cdot 26^{\mathrm{b}}$ & 0.047 & 0.006 \\
\hline $\mathrm{pH}$ & 7.42 & 7.42 & $7 \cdot 41$ & 0.013 & 0.42 \\
\hline \multicolumn{6}{|l|}{ Plasma } \\
\hline Total protein $(\mathrm{mg} / \mathrm{ml})$ & $69 \cdot 8$ & $70 \cdot 3$ & 68.6 & $3 \cdot 26$ & 0.81 \\
\hline Albumin (g/l) & 28.9 & $31 \cdot 0$ & 28.4 & $2 \cdot 66$ & 0.45 \\
\hline Total $\mathrm{Ca}(\mathrm{mm})$ & $2 \cdot 66^{\mathrm{a}}$ & $2 \cdot 50^{\mathrm{a}}$ & $2 \cdot 32^{\mathrm{b}}$ & $0 \cdot 12$ & 0.013 \\
\hline$P_{i}(\mathrm{~mm})$ & 1.71 & 1.79 & 1.89 & 0.30 & 0.78 \\
\hline $\mathrm{Na}^{+}(\mathrm{mM})$ & 141.7 & 140.9 & $143 \cdot 2$ & 1.32 & 0.13 \\
\hline Calcidiol (mм) & 14.66 & $16 \cdot 94$ & $18 \cdot 22$ & 4.92 & 0.68 \\
\hline Calcitriol (pg/ml) & $46 \cdot 80$ & 39.89 & 31.63 & 7.07 & 0.06 \\
\hline Growth hormone (ng/ml) & $7 \cdot 3$ & $6 \cdot 7$ & $12 \cdot 8$ & $5 \cdot 61$ & 0.38 \\
\hline IGF-1 (ng/ml) & $181^{a}$ & $175^{a}$ & $46 \cdot 2^{b}$ & 51 & 0.009 \\
\hline \multicolumn{6}{|l|}{ Fractional excretion of (\%) } \\
\hline$n$ & 6 & 7 & 6 & & \\
\hline Urea & $93 \cdot 4^{\mathrm{a}}$ & $43 \cdot 3^{\mathrm{a}, \mathrm{c}}$ & $7 \cdot 9^{b, c}$ & $27 \cdot 8$ & 0.007 \\
\hline $\mathrm{Ca}$ & $3 \cdot 12^{a}$ & $1 \cdot 12^{\mathrm{b}}$ & $1 \cdot 26^{\mathrm{b}}$ & 0.85 & 0.02 \\
\hline $\mathrm{P}_{\mathrm{i}}$ & $1 \cdot 16$ & 0.97 & 0.77 & 0.20 & 0.10 \\
\hline $\mathrm{Na}^{+}$ & 0.39 & 0.77 & 0.54 & 0.51 & 0.65 \\
\hline
\end{tabular}

$\mathrm{CP}$, crude protein; IGF-1, insulin-like growth factor-1; $\mathrm{P}_{\mathrm{i}}$, inorganic phosphate.

a,b,c Mean values within a row with unlike superscript letters were significantly different $(P<0.05)$.

* Fractional excretion of urea, $\mathrm{Ca}, \mathrm{P}_{\mathrm{i}}$ and $\mathrm{Na}^{+}$of goats fed different $\mathrm{N}$ and $\mathrm{Ca}$ supply.

† Values in the $19 \% \mathrm{CP}$ and $7 \% \mathrm{CP}$ columns for ionised $\mathrm{Ca}$, total $\mathrm{CA}, \mathrm{P}_{\mathrm{i}}$, calcidiol and calcidiol have previously been published in Muscher et al. ${ }^{(12)}$. 
Table 4. Transepithelial conductance $\left(G_{\mathrm{T}}\right.$, in $\left.\mathrm{mS} / \mathrm{cm}^{2}\right)$, short-circuit current $\left(I_{\mathrm{sc}}\right.$, in $\left.\mu \mathrm{Eq} /\left(\mathrm{cm}^{2} \times \mathrm{h}\right)\right)$, mucosal-to-serosal $\left(J_{\mathrm{ms}}\right)$ in $\mathrm{nmol} /\left(\mathrm{cm}^{2} \times \mathrm{h}\right)$, serosal-to-mucosal $\left(J_{\mathrm{sm}}\right)$ in $\mathrm{nmol} /\left(\mathrm{cm}^{2} \times \mathrm{h}\right)$ and net flux rates $\left(J_{\text {net }}=\right.$ $\left.J_{m s}-J_{s m}\right)$ flux rates of calcium, inorganic phosphate $\left(P_{i}\right)$ and mannitol (man) in goat proximal jejunum and mid-jejunum as affected by dietary nitrogen and calcium supply

(Mean values and pooled standard errors)

\begin{tabular}{|c|c|c|c|c|c|}
\hline Item & $19 \% \mathrm{CP}$ & $10 \% \mathrm{CP}$ & $7 \% \mathrm{CP}$ & SEM & $P$ \\
\hline$n$ & 7 & 7 & 6 & & \\
\hline \multicolumn{6}{|c|}{ Proximal jejunum } \\
\hline$G_{T}$ & $11 \cdot 8$ & $13 \cdot 3$ & $14 \cdot 8$ & 1.75 & 0.14 \\
\hline$I_{S C}$ & $0.42^{\mathrm{a}}$ & $0.48^{a}$ & $1.29^{b}$ & 0.22 & $<0.001$ \\
\hline$J_{\mathrm{msCa}}$ & $35 \cdot 0^{\mathrm{a}}$ & $39 \cdot 4^{\mathrm{a}}$ & $76 \cdot 1^{\mathrm{b}}$ & 9.35 & $<0.001$ \\
\hline$J_{\mathrm{sm} \mathrm{Ca}}$ & $31 \cdot 0$ & $27 \cdot 3$ & $32 \cdot 7$ & 5.95 & 0.54 \\
\hline$J_{\text {net Ca }}$ & $4 \cdot 08^{a}$ & $12 \cdot 0^{a}$ & $43 \cdot 4^{\mathrm{b}}$ & 6.06 & $<0.001$ \\
\hline \multicolumn{6}{|c|}{ Mid-jejunum } \\
\hline$G_{\top}$ & $10 \cdot 7$ & $11 \cdot 8$ & 14.5 & $2 \cdot 10$ & 0.11 \\
\hline$I_{\mathrm{SC}}$ & $0.63^{a}$ & $0.64^{a}$ & $1.25^{\mathrm{b}}$ & 0.17 & $<0.001$ \\
\hline$J_{\mathrm{ms} C a}$ & 35.4 & $35 \cdot 3$ & 34.6 & $5 \cdot 12$ & 0.98 \\
\hline$J_{\mathrm{sm} \mathrm{Ca}}$ & $38 \cdot 8$ & 37.9 & $26 \cdot 3$ & $6 \cdot 38$ & 0.06 \\
\hline$J_{\text {net Ca }}$ & $-3.40^{\mathrm{a}}$ & $-2 \cdot 58^{a}$ & $8 \cdot 26^{b}$ & $4 \cdot 22$ & 0.007 \\
\hline$J_{\mathrm{ms} P i}$ & 132 & 146 & 213 & 40.4 & 0.06 \\
\hline$J_{\mathrm{sm} \mathrm{Pi}}$ & $37.8^{\mathrm{a}}$ & $34 \cdot 8^{a, b}$ & $28 \cdot 5^{b}$ & 4.23 & 0.049 \\
\hline$J_{\text {netPi }}$ & $94.5^{\mathrm{a}}$ & $111^{a, b}$ & $184^{\mathrm{b}}$ & 41.7 & 0.045 \\
\hline$J_{\text {ms man }}$ & $48 \cdot 2^{\mathrm{a}, \mathrm{b}}$ & $44.4^{\mathrm{a}}$ & $58 \cdot 2^{b}$ & 5.77 & 0.029 \\
\hline$J_{\text {sm man }}$ & $36 \cdot 8^{\mathrm{a}}$ & $32 \cdot 6^{a, b}$ & $22 \cdot 6^{\mathrm{b}}$ & 5.43 & 0.017 \\
\hline$J_{\text {net man }}$ & $11.4^{\mathrm{a}}$ & $11 \cdot 8^{\mathrm{a}}$ & $35 \cdot 7^{\mathrm{b}}$ & 9.28 & 0.009 \\
\hline
\end{tabular}

$\mathrm{CP}$, crude protein.

a,b Mean values within a row with unlike superscript letters were significantly different $(P<0.05)$.

indicating that there was neither haemoconcentration nor haemodilution with the various diets (Table 3). Both, total and ionised plasma Ca concentrations were significantly reduced, while blood $\mathrm{pH}$ was not influenced in the goats fed a reduced $\mathrm{N}$ diet with varied $\mathrm{Ca}$ content ${ }^{(12)}$ (Table 3 ). The concentrations of plasma $\mathrm{P}_{\mathrm{i}}$ and $\mathrm{Na}^{+}$were not affected by changes in this feeding regime in the young goats (Table 3). Plasma calcidiol concentrations remained unchanged, while calcitriol concentrations tended to be reduced $(P=0 \cdot 06)$ when dietary $\mathrm{N}$ was decreased (Table 3). The decline in plasma IGF-1 concentrations was positively related to plasma urea levels $\left(r^{2}\right.$ $0 \cdot 278, P=0.021)$ while concentrations of growth hormone were not affected (Table 3). Some of these blood parameters have already been published in the work by Muscher et al. ${ }^{(12)}$.

Fractional excretion of urea, calcium, inorganic phosphate and sodium as affected by the reduction of dietary nitrogen and calcium in growing goats

The reduction of dietary $\mathrm{N}$ and $\mathrm{Ca}$ resulted in decreases of $\mathrm{FE}$ of urea and $\mathrm{Ca}$. The FE of $\mathrm{P}_{\mathrm{i}}$ tended to be reduced $(P=0 \cdot 10)$ while the $\mathrm{FE}$ of $\mathrm{Na}^{+}$remained unaffected (Table 3 ).

\section{Electrophysiological properties as affected by the} reduction of dietary nitrogen and calcium in growing goats

For both epithelia, tissue conductance was not affected by changes in the diet, while basal short-circuit current of the $7 \% \mathrm{CP}$ group in both the intestinal segments increased in comparison with the two other feeding groups (Table 4).
Flux rates of calcium and inorganic phosphate across intestinal mucosa as affected by the reduction of dietary nitrogen and calcium in growing goats

In growing goats fed a reduced $\mathrm{N}$ and $\mathrm{Ca}$ diet, the $J_{\mathrm{ms}}$ flux rates of $\mathrm{Ca}$ in the proximal jejunum were elevated in the animals of the $7 \% \mathrm{CP}$ group without having any effect on the $J_{\mathrm{sm}}$ flux rates, resulting in increased $J_{\text {net }}$ in these animals in comparison with the 19\% CP and 10\% CP groups (Table 4). In mid-jejunum, the $J_{\mathrm{ms}}$ flux rates of Ca were not influenced by the dietary treatment while $J_{\mathrm{sm}}$ flux rates of Ca were only tendentially affected, which still resulted in an increase of $J_{\text {net }}$ flux rates for the animals in the $7 \%$ CP group in comparison with both other groups (Table 4). The $\mathrm{Na}^{+}$-dependent $\mathrm{P}_{\mathrm{i}}$ transport was measured in mid-jejunum as the main absorption site for $P_{i}$ in goats ${ }^{(20,33)}$. A transfer of $P_{i}$ across the intestinal epithelium from the mucosal to the serosal side as well as from the serosal to the mucosal side could be detected in all animals (Table 4). The reduction of dietary $\mathrm{N}$ and Ca supply increased the $J_{\mathrm{ms}}$ flux rates of $\mathrm{P}_{\mathrm{i}}$ while the $J_{\mathrm{sm}}$ flux rates were decreased, which resulted in significantly higher $J_{\text {net }}$ flux rates of $\mathrm{P}_{\mathrm{i}}$ in the goats fed a $7 \% \mathrm{CP}$ diet (Table 4). The changes of the dietary $\mathrm{N}$ and $\mathrm{Ca}$ content had an impact on
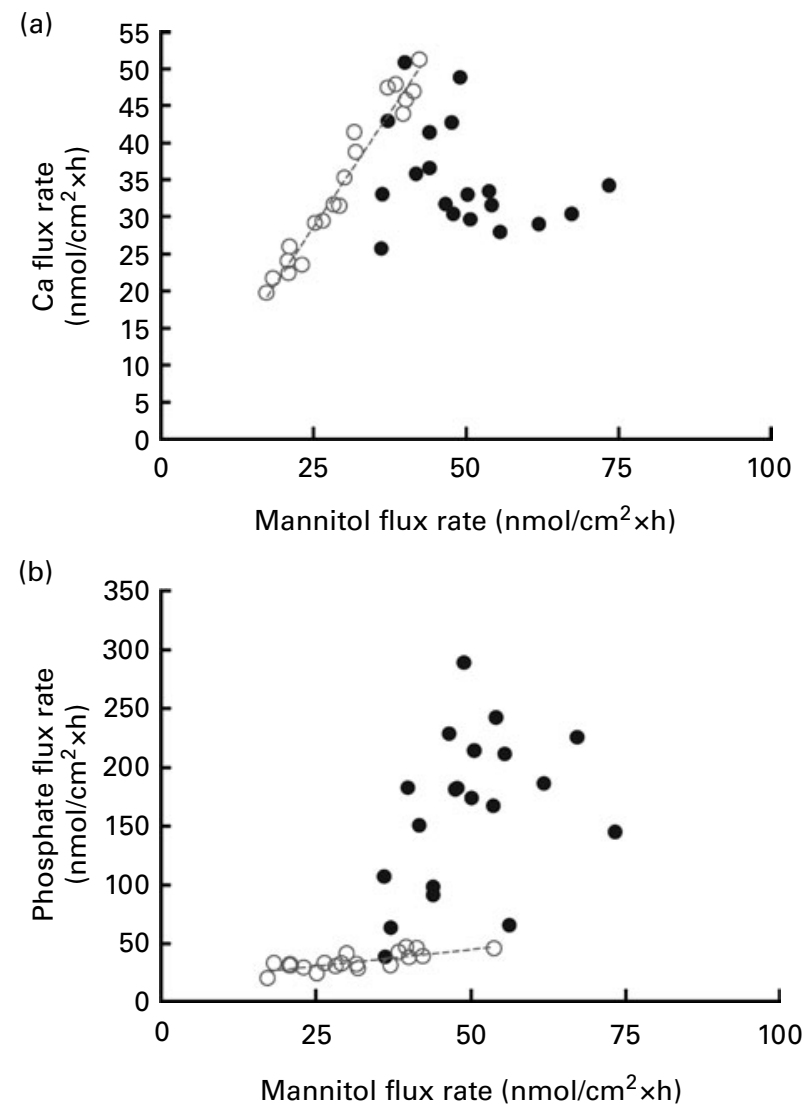

Fig. 1. Linear regression of unidirectional mucosal to serosal $\left(J_{\mathrm{ms}} ; 0\right)$ or serosal to mucosal $\left(J_{\mathrm{sm}} ; 0,-. .-\right)$ flux rates of (a) calcium $\left(J_{\mathrm{sm}} \mathrm{Ca}=(1.24 \pm 0.06) J_{\mathrm{sm}}\right.$ mannitol $\left.-(2.33 \pm 1.96), r^{2} 0.96, P<0.001\right)$ or (b) inorganic phosphate $\left(\mathrm{P}_{\mathrm{i}} ; \quad J_{\mathrm{sm}} \mathrm{P}_{\mathrm{i}}=(0.56 \pm 0.11) \quad J_{\mathrm{sm}}\right.$ mannitol+ (16.45 \pm 3.59$\left.), r^{2} 0.59, P<0.001\right)$ with the corresponding mannitol flux rates in mid-jejunum of goats fed different nitrogen and $\mathrm{Ca}$ diets. Calculations were only provided when significance was obtained by linear regression. 
the mannitol flux rates in mid-jejunum, too. The $J_{\mathrm{ms}}$ flux rates of mannitol were elevated in the $7 \% \mathrm{CP}$ group in comparison with the other two diets while the $J_{\text {sm }}$ flux rates of mannitol were reduced, causing an increase of $J_{\text {net }}$ flux rates of mannitol in the $7 \% \mathrm{CP}$ group (Table 4). High significant correlations between $J_{\mathrm{sm}}$ mannitol and $J_{\mathrm{sm}} \mathrm{Ca}$ flux rates $(P<0.001$; Fig. 1(a)) and between $J_{\mathrm{sm}}$ mannitol and $J_{\mathrm{sm}} \mathrm{P}_{\mathrm{i}}$ flux rates $(P<0.001)$, respectively, could be revealed by linear regression (Fig. 1(b)).

\section{Intestinal uptake of calcium and inorganic phosphate in} isolated brush-border membrane vesicles as affected by the reduction of dietary nitrogen and calcium in growing goats

The functional integrity of the isolated BBMV from proximal and mid-jejunum was tested by performing a respective successful characteristic $\mathrm{Na}^{+}$-dependent overshoot phenomenon of glucose uptake (data not shown). The reduction of dietary $\mathrm{N}$ and $\mathrm{Ca}$ had no effect on the kinetic parameters like transport capacity $\left(V_{\max }\right)$ and transporter affinity $\left(K_{\mathrm{m}}\right)$ of $\mathrm{Ca}$ and $\mathrm{P}_{\mathrm{i}}$ uptake in the isolated BBMV of proximal and mid-jejunum (Table 5).

\section{Intestinal expression of sodium-dependent phosphate} transporter IIb and vitamin $D$ receptor $m R N A$ as affected by the reduction of dietary nitrogen and calcium in growing goats

A reduction of dietary $\mathrm{N}$ and $\mathrm{Ca}$ caused a tendential increase of NaPi IIb-specific mRNA in mid-jejunum, while neither the expression patterns nor the expression amounts of VDRspecific mRNA in proximal and mid-jejunum were affected in the growing goats (Table 5).
Intestinal expression of transient receptor potential vanilloid channel type 6, sodium-dependent phosphate transporter $\| \mathrm{l} b$, vitamin $D$ receptor and $\mathrm{Na}^{+} K^{+}$ATPase protein as affected by the reduction of dietary nitrogen and calcium in growing goats

The protein expression of the Ca channel, TRPV6, was significantly reduced in the crude membranes of proximal jejunum in goats in the $7 \%$ CP group in comparison with the $19 \%$ $\mathrm{CP}$ group (Table 5). The reduction of dietary $\mathrm{N}$ and Ca content had no impact on the protein amount of the nuclear located VDR either in proximal or in mid-jejunum in the growing goats (Table 5). Changes in the $\mathrm{Na}^{+} \mathrm{K}^{+}$ATPase protein expression could not be detected in the crude membranes of proximal and mid-jejunum (Table 5). In mid-jejunum, the protein expression of the $\mathrm{Na}^{+}$-dependent $\mathrm{P}_{\mathrm{i}}$ transporter, $\mathrm{NaPi}$ IIb, was significantly reduced in the $7 \% \mathrm{CP}$ group in comparison with the animals fed 19\% CP (Table 5). Additionally, the NaPi IIb protein expression was positively correlated with the plasma calcitriol concentrations of these animals $\left(r^{2} 0.353, P=0.032\right)$.

\section{Discussion}

The aim of the present study was to investigate whether the intestinal absorption of $\mathrm{Ca}$ and $\mathrm{P}_{\mathrm{i}}$ is modulated by a concomitant reduction of dietary $\mathrm{N}$ and $\mathrm{Ca}$ supply in goats. With the present study, it could be shown for the first time that a reduction of $\mathrm{N}$ and $\mathrm{Ca}$ intake has an impact on $\mathrm{Ca}$ and $\mathrm{P}_{\mathrm{i}}$ absorption in caprine intestinal epithelia. However, limitations of the present study were that the effects of a dietary $\mathrm{N}$ or $\mathrm{Ca}$ reduction were not examined separately. No individual feed intakes of the goats were monitored, but the animal was still acceptable as the experimental unit for all other data of this

Table 5. Relative amounts of sodium-dependent phosphate transporter (NaPi) Ilb and vitamin $\mathrm{D}$ receptor (VDR) mRNA expression as well as relative amounts of $\mathrm{NaPi} \mathrm{llb}$, transient receptor potential vanilloid channel type 6 (TRPV6), VDR and $\mathrm{Na}^{+} \mathrm{K}^{+}$ATPase protein expression in proximal and mid-jejunum in goats fed different nitrogen and calcium diets*

(Mean values with their standard errors)

\begin{tabular}{|c|c|c|c|c|c|}
\hline Item & $19 \% \mathrm{CP}$ & $10 \% \mathrm{CP}$ & $7 \% \mathrm{CP}$ & SEM & $P$ \\
\hline$n$ & 7 & 7 & 6 & & \\
\hline \multicolumn{6}{|l|}{ Proximal jejunum } \\
\hline$V_{\max }(\mathrm{nmol} \mathrm{Ca} /(\mathrm{mg}$ protein $\times 30 \mathrm{~s}))$ & $4 \cdot 29$ & $6 \cdot 88$ & $8 \cdot 14$ & 2.56 & 0.20 \\
\hline$K_{\mathrm{m}}(\mathrm{mmol} \mathrm{Ca} / \mathrm{l})$ & 3.44 & $6 \cdot 89$ & 8.33 & 2.90 & 0.14 \\
\hline VDR mRNA:B-actin mRNA ratio & 0.31 & ND & 0.32 & 0.03 & 0.98 \\
\hline TRPV6 protein:villin protein ratio & 0.77 & ND & 0.40 & 0.15 & 0.03 \\
\hline VDR protein:villin protein ratio & 1.29 & ND & 1.45 & 0.33 & 0.64 \\
\hline $\mathrm{Na}^{+} \mathrm{K}^{+}$ATPase protein:villin protein ratio & 0.87 & ND & 1.01 & 0.13 & 0.30 \\
\hline \multicolumn{6}{|l|}{ Mid-jejunum } \\
\hline$V_{\max }\left(\mathrm{nmol} \mathrm{P}_{\mathrm{i}} /(\mathrm{mg}\right.$ protein $\left.\times 10 \mathrm{~s})\right)$ & 0.51 & 0.56 & 0.46 & $0 \cdot 10$ & 0.52 \\
\hline$K_{\mathrm{m}}\left(\mathrm{mmol} \mathrm{P}_{\mathrm{i}} / \mathrm{l}\right)$ & 0.04 & 0.04 & 0.03 & 0.01 & 0.77 \\
\hline NaPi llb mRNA:B-actin mRNA ratio & $1 \cdot 11$ & ND & 1.42 & $0 \cdot 16$ & 0.08 \\
\hline VDR mRNA:ß-actin mRNA ratio & 0.18 & ND & 0.22 & 0.03 & 0.25 \\
\hline $\mathrm{NaPi}$ llb protein:villin protein ratio & $2 \cdot 10$ & ND & 0.84 & 0.46 & 0.02 \\
\hline VDR protein:villin protein ratio & $2 \cdot 41$ & ND & $2 \cdot 19$ & 0.36 & 0.56 \\
\hline $\mathrm{Na}^{+} \mathrm{K}^{+}$ATPase protein:villin protein ratio & $4 \cdot 26$ & ND & $4 \cdot 77$ & 1.25 & 0.69 \\
\hline
\end{tabular}

$\mathrm{CP}$, crude protein; $V_{\max }$, maximal transport rate; $K_{\mathrm{m}}$, half-maximal saturation value; ND, not determined; $\mathrm{P}_{\mathrm{i}}$, inorganic phosphate.

* Kinetic parameters, $V_{\max }$ and $K_{\mathrm{m}}$, of $\mathrm{Ca}$ and $\mathrm{Na}^{+}$-dependent $\mathrm{P}_{\mathrm{i}}$ uptake in caprine small-intestinal brush-border membrane vesicles of goats fed different $\mathrm{N}$ and $\mathrm{Ca}$ diets. 
study because final BW of each animal, which was recorded individually, was not affected while plasma urea concentrations were concomitantly diminished like the percentage of $\mathrm{N}$ in the diets. For this reason, we decided to calculate with individual animals as animals having received a groupspecific treatment (19\% CP, $10 \% \mathrm{CP}$ and $7 \% \mathrm{CP})$.

To characterise the metabolic status of the goats fed a reduced $\mathrm{N}$ and $\mathrm{Ca}$ diet, concentrations of IGF-1, growth hormone and calcitriol were determined. All three parameters were consistent with the concentrations from goats fed a reduced $\mathrm{N}$ diet under normocalcaemic conditions ${ }^{(13)}$.

In proximal jejunum, the major intestinal site for Ca absorption in small ruminants ${ }^{(34,36)}$, the $J_{\mathrm{ms}}$ flux rates of Ca were significantly increased, while the $J_{\mathrm{sm}}$ flux rates of Ca remained constant. This resulted in significant increases in $J_{\text {net }}$ flux rates, indicating a stimulatory effect on active Ca transport in response to reductions in $\mathrm{N}$ and $\mathrm{Ca}$ intake. In order to differentiate between the para- and transcellular component of unidirectional Ca flux rates, the paracellular marker mannitol was used as introduced by Auchere et al. ${ }^{(22)}$. For technical reasons, mannitol flux rates could only be measured in mid-jejunum. At this site, Ca flux rates from the serosal to the mucosal side correlated significantly with the respective mannitol flux rates, whereas no correlation could be detected for $J_{\mathrm{ms}}$ (Fig. 1(a)). From these correlations it can be concluded that these $\mathrm{Ca}$ flux rates were mainly mediated by active, transcellular transport mechanisms. Suggesting that the transcellular pathway was the major route for $J_{\mathrm{ms}}$ Ca flux rates, the dietary reduction of $\mathrm{N}$ and $\mathrm{Ca}$ would have had a stimulatory effect on the active absorption of $\mathrm{Ca}$ in proximal jejunum of growing goats.

However, the mechanisms by which the modulation of intestinal electrolyte transport in response to reduced $\mathrm{N}$ and $\mathrm{Ca}$ intake are mediated are not yet understood. Interestingly, a reduced $\mathrm{N}$ and $\mathrm{Ca}$ diet led to low plasma Ca concentrations, which were not observed in goats or rats fed a low-Ca diet only ${ }^{(36,37)}$. Physiologically, a low-Ca diet led to elevated plasma calcitriol concentrations in single-stomached animals and ruminants ${ }^{(36,37)}$. An increase in plasma calcitriol is responsible for the stimulation of intestinal $\mathrm{Ca}$ absorption in singlestomached animals ${ }^{(37)}$. In sheep, the stimulation of jejunal Ca absorption was only detected in response to supraphysiological dosage of exogenous calcitriol ${ }^{(34)}$. When only dietary $\mathrm{Ca}$ intake was reduced, no effects on intestinal $\mathrm{Ca}$ transport were detected in goats and sheep ${ }^{(34,36)}$. Therefore, a stimulation of endogenous calcitriol production by the diet has modulatory effects on the intestinal absorption of $\mathrm{Ca}$ in single-stomached animals. However, this effect could not be seen in small ruminants. In contrast, the findings of the present study showed low plasma $\mathrm{Ca}$ concentrations and low calcitriol concentrations but a high $\mathrm{Ca}$ absorption across the intestinal epithelium, indicating a lack of stimulation of calcitriol synthesis by low plasma Ca levels in goats fed a reduced $\mathrm{N}$ and $\mathrm{Ca}$ diet.

The mid-jejunal $J_{\mathrm{ms}}$ flux rates of mannitol increased in the $7 \%$ CP group while the $J_{\text {sm }}$ flux rates decreased, resulting in an increase of $J_{\text {net }}$ flux rates of mannitol in response to the reduced $\mathrm{N}$ and $\mathrm{Ca}$ diet. This increase of $J_{\text {net }}$ flux rates of mannitol was induced by a greater permeability of the epithelium in mid-jejunum, which might have caused the increase of passive $\mathrm{Ca}$ absorption in mid-jejunum of goats fed a reduced $\mathrm{N}$ and $\mathrm{Ca}$ diet. The reason for the greater permeability of the epithelium for $\mathrm{Ca}$ during a reduced protein or reduced $\mathrm{N}$ and $\mathrm{Ca}$ diet is as yet unknown. The expression level of tight junction proteins like claudin- 2 or claudin- 12 could be stimulated, both of which function as paracellular Ca channels in single-stomached animals ${ }^{(38)}$.

The increases of the net flux rates of $P_{i}$ in mid-jejunum during a reduced $\mathrm{N}$ diet could not be completely explained by a higher permeability of the epithelium for $P_{i}$ because only the $J_{\text {sm }}$ flux rates of $\mathrm{P}_{\mathrm{i}}$, which were decreased, correlated with the corresponding mannitol fluxes (Fig. 1(b)). The $J_{\mathrm{ms}}$ flux rates of $\mathrm{P}_{\mathrm{i}}$ increased during the reduction of the dietary $\mathrm{N}$ which resulted in an increase of the $J_{\text {net }}$ flux rates of $\mathrm{P}_{\mathrm{i}}$. This increase of $J_{\mathrm{ms}}$ flux rates of $\mathrm{P}_{\mathrm{i}}$ could not be correlated with the corresponding mannitol flux rates (Fig. 1(b)). Therefore, it has to be concluded that the reduction of the dietary $\mathrm{N}$ and $\mathrm{Ca}$ caused an increase of the active, transcellular $\mathrm{Na}^{+}{ }_{-}$ dependent $\mathrm{P}_{\mathrm{i}}$ absorption in mid-jejunum in growing goats.

To investigate the molecular basis of the increase of intestinal net flux rates of $\mathrm{Ca}$ and $\mathrm{P}_{\mathrm{i}}$, we performed uptake studies with BBMV from proximal and mid-jejunum to evaluate if the suggested rate-limiting step, the apical uptake of both electrolytes, could be modulated by changes in dietary $\mathrm{N}$ and $\mathrm{Ca}$. Actually, the uptake of $\mathrm{Ca}$ and $\mathrm{P}_{\mathrm{i}}$ into isolated BBMV was not affected at all, in contrast to results of uptake studies from Gaffney-Stomberg et al. ${ }^{(9)}$, who showed that a reduction of dietary protein under normocalcaemic conditions caused a decrease of intestinal apical uptake of $\mathrm{Ca}$ in rats. The discrepancy between the results performed in Ussing chambers and the data received from uptake studies cannot be explained yet. A possible stimulation of the basolateral located $\mathrm{Na}^{+} \mathrm{K}^{+}$ATPase could be discussed, which would increase the extrusion of $\mathrm{Na}^{+}$, generating a higher $\mathrm{Na}^{+}$gradient as a driving force for $\mathrm{Na}^{+}$-dependent transport processes such as $\mathrm{P}_{\mathrm{i}}$ or other substrates like glucose in Ussing chamber experiments. Even though apical located $\mathrm{Na}^{+}$-dependent $\mathrm{P}_{\mathrm{i}}$ transporter NaPi IIb was decreased during a reduced $\mathrm{N}$ and Ca diet, a hypothetically enhanced $\mathrm{Na}^{+}$gradient could potentially compensate for the transporter reduction, which would result in higher intestinal stimulation of $\mathrm{Na}^{+}$-dependent COtransport systems like $\mathrm{P}_{\mathrm{i}}$ and glucose during a reduced $\mathrm{N}$ and $\mathrm{Ca}$ diet in growing goats.

Furthermore, the mRNA expression of the intestinal $\mathrm{Na}^{+}$dependent $\mathrm{P}_{\mathrm{i}}$ transporter, NaPi IIb, and the VDR, was not modulated by a reduction of dietary $\mathrm{N}$ and $\mathrm{Ca}$ in growing goats. Interestingly, the protein expressions of the Ca channel TRPV6 and the $\mathrm{P}_{\mathrm{i}}$ transporter NaPi IIb were reduced in the goats in the $7 \% \mathrm{CP}$ group compared to those animals in the $19 \%$ CP group, while the protein expression of the VDR in both epithelia was not affected. The low plasma calcitriol concentrations in the $7 \% \mathrm{CP}$ could be the reason for the reduction of TRPV6 and NaPi IIb protein expression, assuming that these processes were calcitriol-dependent like in singlestomached animals ${ }^{(14-16)}$.

However, the reduction of protein expression did not verify the higher intestinal net flux rates for $\mathrm{Ca}$ and $\mathrm{P}_{\mathrm{i}}$. Besides the 
enhancement of the $\mathrm{Na}^{+}$gradient by $\mathrm{Na}^{+} \mathrm{K}^{+}$ATPase, additional $\mathrm{Na}^{+}$-dependent transporting systems might have been activated during a reduced $\mathrm{N}$ and $\mathrm{Ca}$ diet in growing goats. A potential candidate could be the L-type Ca channel $\mathrm{Ca}_{\mathrm{v}} 1 \cdot 3$, which is expressed in the jejunum of rats ${ }^{(39)}$. The inhibition of $\mathrm{Na}^{+}$-dependent glucose absorption by phlorizin strongly inhibited intestinal Ca absorption in these rats. Therefore, it was suggested that during a meal, glucose, amino acids and oligopeptide transport caused a depolarisation of the apical membrane, which induced the $\mathrm{Ca}$ absorption through L-type $\mathrm{Ca}$ channels $\mathrm{Ca}_{\mathrm{v}} 1 \cdot 3^{(39)}$. Such a depolarisation of the apical membrane was expected during a reduced $\mathrm{N}$ and $\mathrm{Ca}$ diet in growing goats, too, because a stimulation of the intestinal absorption of glucose could also be observed in these animals (AS Muscher, unpublished results). Therefore, it is hypothesised that this depolarisation could be a reason for the stimulated $\mathrm{Ca}$ absorption by the activation of $\mathrm{Ca}_{\mathrm{v}} 1.3$ in proximal jejunum of goats fed a reduced $\mathrm{N}$ and $\mathrm{Ca}$ diet.

From the present study, it can be concluded that the classical activation of calcitriol by low plasma Ca concentrations does not exist in growing goats fed a reduced $\mathrm{N}$ and $\mathrm{Ca}$ diet. In contrast to the situation in sheep and goats fed a low-Ca diet only, the intestinal absorption of $\mathrm{Ca}$ and $\mathrm{P}_{\mathrm{i}}$ was stimulated by this feeding regimen. The involvement of additional transport systems like the L-type $\mathrm{Ca}$ channel $\mathrm{Ca}_{\mathrm{v}}$ 1.3 and a potential activation of the basolateral located $\mathrm{Na}^{+} \mathrm{K}^{+-}$ ATPase cannot be excluded. Further studies are necessary to characterise the nature of the stimulated electrolyte transport in growing goats fed a reduced $\mathrm{N}$ and $\mathrm{Ca}$ diet. Additionally, the results of the present study must be evaluated to ascertain whether a reduction of dietary $\mathrm{N}$ with adequate $\mathrm{Ca}$ levels would also affect intestinal electrolyte absorption in the same manner as seen under hypocalcaemic conditions.

\section{Acknowledgements}

This project was supported by the German Research Foundation (DFG). The authors wish to thank M. Burmester, K. Hansen and K. Hustedt for their technical assistance. The authors also thank Dr M. Piechotta (Clinic for Cattle, University of Veterinary Medicine Hannover, Germany) for performing the assay of IGF-1 and growth hormone in plasma, and Professor Dr J. Biber and Professor Dr H. Murer for supplying the NaPi IIb antibody (Institute of Physiology, University of Zurich-Irchel, Zurich, Switzerland). A. S. M., K. H. and G. B. designed the experiments; A. S. M., M. R. W., N. M. and B. S. conducted the research; A. S. M., M. R. W., N. M. and B. S. analysed the data; and A. S. M. wrote the paper. All authors discussed the results and commented on them in the manuscript. The authors declare that there are no conflicts of interest.

\section{References}

1. Eriksson L \& Valtonen M (1982) Renal urea handling in goats fed high and low protein diets. J Dairy Sci 65, 385-389.

2. Silanikove N (1984) Renal excretion of urea in response to changes in nitrogen intake in desert (black Bedouin) and non-desert (Swiss Saanen) goats. Comp Biochem Physiol A Comp Physiol 79, 651-654

3. Muscher AS, Schroder B, Breves G, et al. (2010) Dietary nitrogen reduction enhances urea transport across goat rumen epithelium. J Anim Sci 88, 3390-3398.

4. Harmeyer J \& Martens H (1980) Aspects of urea metabolism in ruminants with reference to the goat. J Dairy Sci $\mathbf{6 3}$, $1707-1728$.

5. Filho JC, Hazel SJ, Anderstam B, et al. (1999) Effect of protein intake on plasma and erythrocyte free amino acids and serum IGF-I and IGFBP-1 levels in rats. Am J Physiol 277, E693-E701.

6. Peng YS, Meliza LL, Vavich MG, et al. (1974) Changes in food intake and nitrogen metabolism of rats while adapting to a low or high protein diet. J Nutr 104, 1008-1017.

7. Schmidt-Nielsen B (1958) Urea excretion in mammals. Physiol Rev 38, 139-168.

8. Orwoll E, Ware M, Stribrska L, et al. (1992) Effects of dietary protein deficiency on mineral metabolism and bone mineral density. Am J Clin Nutr 56, 314-319.

9. Gaffney-Stomberg E, Sun BH, Cucchi CE, et al. (2010) The effect of dietary protein on intestinal calcium absorption in rats. Endocrinology 151, 1071-1078.

10. Kerstetter JE, O'Brien KO \& Insogna KL (1998) Dietary protein affects intestinal calcium absorption. Am J Clin Nutr $\mathbf{6 8}$, $859-865$.

11. GfE (2003) Recommendations for the Supply of Energy and Nutrients to Goats. The Committee for Requirement Standards of the Society of Nutrient Physiology Report no. 9. Frankfurt am Main: DLG-Verlag.

12. Muscher A \& Huber K (2010) Effects of a reduced nitrogen diet on calcitriol levels and calcium metabolism in growing goats. J Steroid Biochem Mol Biol 121, 304-307.

13. Muscher AS, Piechotta M, Breves G, et al. (2011) Modulation of electrolyte homeostasis by dietary nitrogen intake in growing goats. Br J Nutr 105, 1619-1626.

14. Van Cromphaut SJ, Dewerchin M, Hoenderop JG, et al. (2001) Duodenal calcium absorption in vitamin D receptorknockout mice: functional and molecular aspects. Proc Natl Acad Sci U S A 98, 13324-13329.

15. Hattenhauer O, Traebert M, Murer H, et al. (1999) Regulation of small intestinal Na-P(i) type IIb cotransporter by dietary phosphate intake. Am J Physiol 277, G756-G762.

16. Yagci A, Werner A, Murer H, et al. (1992) Effect of rabbit duodenal mRNA on phosphate transport in Xenopus laevis oocytes: dependence on 1,25-dihydroxy-vitamin- $\mathrm{D}_{3}$. Pflugers Arch 422, 211-216.

17. Ireland P \& Fordtran JS (1973) Effect of dietary calcium and age on jejunal calcium absorption in humans studied by intestinal perfusion. J Clin Invest 52, 2672-2681.

18. Frolik CA \& DeLuca HF (1972) Metabolism of 1,25-dihydroxycholecalciferol in the rat. J Clin Invest 51, 2900-2906.

19. Naumann C \& Basler R (1976) Verband deutscher landwirtschaftlicher Untersuchungs- und Forschungsanstalten. Methodenbuch Band III. Die chemische Untersuchung von Futtermitteln. Mit Ergänzungslieferungen 1983, 1993, 1997 (Association of German Agricultural Testing and Research Institutes. Methods Book Volume III. The chemical analysis of feed. With additional deliveries in 1983, 1993, 1997). Darmstadt: VDLUFA-Verlag.

20. Schröder B, Kappner H, Failing K, et al. (1995) Mechanisms of intestinal phosphate transport in small ruminants. $\mathrm{Br} J$ Nutr 74, 635-648.

21. Schröder B, Hattenhauer O \& Breves G (1998) Phosphate transport in pig proximal small intestines during postnatal 
development: lack of modulation by calcitriol. Endocrinology 139, 1500-1507.

22. Auchere D, Tardivel S, Gounelle JC, et al. (1998) Role of transcellular pathway in ileal $\mathrm{Ca}^{2+}$ absorption: stimulation by low-Ca ${ }^{2+}$ diet. Am J Physiol 275, G951-G956.

23. Schultz SG \& Zalusky R (1964) Ion transport in isolated rabbit ileum. I. Short-circuit current and Na fluxes. J Gen Physiol 47, 567-584.

24. Sarkar BC \& Chauhan UP (1967) A new method for determining micro quantities of calcium in biological materials. Anal Biochem 20, 155-166.

25. Kruse-Jarres J (1979) Klinische Chemie, spezielle klinischchemische Analytik (Clinical Chemistry, Special ClinicalChemical Analysis). Stuttgart: Fischer-Verlag.

26. Muscher A, Hattendorf J, Pfeffer E, et al. (2008) Hormonal regulation of phosphate homeostasis in goats during transition to rumination. J Comp Physiol B 178, 585-596.

27. Schröder B \& Breves G (1996) Mechanisms of phosphate uptake into brush-border membrane vesicles from goat jejunum. J Comp Physiol B 166, 230-240.

28. Widiyono I, Huber K, Failing K, et al. (1998) Renal phosphate excretion in goats. Zentralbl Veterinarmed $A \mathbf{4 5}$, $145-153$.

29. Roh SG, Matsunaga N, Miyamoto A, et al. (1997) Competitive enzyme immunoassay for bovine growth hormone. Endocr J 44, 195-198.

30. Kawashima C, Sakaguchi M, Suzuki T, et al. (2007) Metabolic profiles in ovulatory and anovulatory primiparous dairy cows during the first follicular wave postpartum. $J$ Reprod Dev 53, 113-120.

31. Valtonen MH, Uusi-Rauva A \& Eriksson L (1982) The effect of protein deprivation on the validity of creatinine and urea in evaluation of renal function. An experimental study in the goat. Scand J Clin Lab Invest 42, 507-512.

32. Kaune R, Kassianoff I, Schroder B, et al. (1992) The effects of 1,25-dihydroxyvitamin D-3 deficiency on $\mathrm{Ca}(2+)$-transport and $\mathrm{Ca}(2+)$-uptake into brush-border membrane vesicles from pig small intestine. Biochim Biophys Acta 1109, 187-194.

33. Huber K, Walter C, Schroder B, et al. (2002) Phosphate transport in the duodenum and jejunum of goats and its adaptation by dietary phosphate and calcium. Am J Physiol Regul Integr Comp Physiol 283, R296-R302.

34. Wilkens MR, Mrochen N, Breves G, et al. (2011) Gastrointestinal calcium absorption in sheep is mostly insensitive to an alimentary induced challenge of calcium homeostasis. Comp Biochem Physiol B Biochem Mol Biol 158, 199-207.

35. Schröder B, Kaune R \& Harmeyer J (1990) Studies of the porcine intestinal calcitriol receptor in pseudo-vitamin D deficiency rickets type I. Clin Sci (Lond) 79, 409-414.

36. Schröder B, Rittmann I, Pfeffer E, et al. (1997) In vitro studies on calcium absorption from the gastrointestinal tract in small ruminants. J Comp Physiol B 167, 43-51.

37. Favus MJ, Mangelsdorf DJ, Tembe V, et al. (1988) Evidence for in vivo upregulation of the intestinal vitamin $\mathrm{D}$ receptor during dietary calcium restriction in the rat. J Clin Invest $\mathbf{8 2}$, 218-224.

38. Fujita H, Sugimoto K, Inatomi S, et al. (2008) Tight junction proteins claudin- 2 and -12 are critical for vitamin D-dependent $\mathrm{Ca}^{2+}$ absorption between enterocytes. Mol Biol Cell 19, 1912-1921.

39. Morgan EL, Mace OJ, Helliwell PA, et al. (2003) A role for $\mathrm{Ca}(\mathrm{v}) 1.3$ in rat intestinal calcium absorption. Biochem Biophys Res Commun 312, 487-493. 